\title{
Tindak Pidana Pencurian yang dilakukan Anak Usia 14 Tahun dalam Konteks Islam Menghapuskan Tindak PidanaBerdasarkan Pasal 69 Ayat 2 Undang-undang Nomor 11 Tahun 2012 Perihal Sistem Peradilan Pidana Anak (SPPA)
}

\author{
Citra Ayu Ramadhanti ${ }^{1}$, Uu Idjuddin Solihin² \\ ${ }^{1}$ Fakultas Hukum, Universitas Singaperbangsa Karawang. Jl. H.S. Ronggo Waluyo, Telukjambe Timur. \\ 2Fakultas Hukum, Universitas Singaperbangsa Karawang. Jl. H.S. Ronggo Waluyo, Telukjambe Timur. \\ Correspondence email: citraxx99@gmail.com, oficiumnobile@gmail.com
}

\begin{abstract}
Abstrak. Anak-anak yang melakukan aksi kriminal harus ditindak secara altruistis, didampingi, diberikan jabatan dan yayasan yang tidak lazim, sanksi yang diberikankepada anak sesuai dengan pedoman kesejahteraan anak, hubungan keluarga dijaga dengan menyiratkan bahwa anak-anak yang berhadapan dengan hukum diperistiwa bahwa mereka tidak dapat dikurung atau ditahan setiap kali ditahan atau dikurung, harus diingat untuk ruang kurungan anak yang luar biasa dan bukan dengan orang dewasa. Untuk menjamin kepastian anak-anak yang berhadapan dengan hukum ditugaskan secara kolektif anak-anak yang membutuhkan keamanan khusus. Dalam pendahuluan hakim, pemeriksa umum, spesialis atau pejabat lainnya tidak mengenakan jubah atau pakaian administrasi, sidang tertutup, dan dengan hakim tunggal. Pencipta menggunakan strategi eksplorasi yuridis regularisasi, yaitu: metodologi yang tergantung pada pengaturan Peraturan perundang-undangan, dengan tata cara pemilihan informasi dalam tinjauan ini adalah dengan memanfaatkan laporan penyelidikan dan setiap informasi yang didapat, dapat diurai secara efisien untuk juga membedah dengan sengaja menggambarkan tugas hakim sejauh melihat dan memilih. kasus anak-anak dengankeputusan yang masuk akal, dengan memfokuskan dan mempertimbangkan kondisi keluarga orang tuanya dan kondisi alam anak khawatir perihal titik bahwa anak dapat memenuhi masa depannya serta dapat diharapkan
\end{abstract}

Kata kunci: Anak, Pelaku, Tindak Pidana Pencurian

\begin{abstract}
Kids who carry out criminal demonstrations should be dealt with altruistically, went with, gave uncommon offices and foundation, sanctions given to kids as per the guideline of the wellbeing of the kid, family connections are kept up with implying that youngsters who face the law in the event that they can not be confinedor detained whenever detained or confined, should be remembered for an extraordinary kid confinement room and not with grown-ups. To guarantee the assurance of youngsters who are confronted with the law is assigned collectively ofkids who need unique security. In the preliminary of the adjudicator, the public examiner, specialist or other official doesn't wear robe or administration garments, shut hearings, and with a solitary judge.The creator utilizes regularizing juridical exploration strategies, specifically: a methodology that depends on the arrangements of the laws and guidelines, with the information assortment procedures in this review is to utilize the investigation of reports and every one of the information got, can be broke down efficiently to additionally dissect deliberately portraying the job of judges as far as looking at and choosing youngsters' cases with reasonable decisions, by focusing and considering the condition of the family of his folks and the natural conditions of the kid worried about the point that the kid can meet his future as well as could be expected.
\end{abstract}

Keywords: Child, Actors, Theft Crimes

PENDAHULUAN

Anak-anak ialah poin yang tak bisa dipisah dari ketahanan manusia serta pemeliharaan negara juga negara, di konstitusi Indonesia kanak-kanak memainkan posisi penting, ini secara eksplisit dipaparkan bahwa negara menanggung setiap anak memiliki pilihan untuk jaminan dari kejahatan dan pemisahan. Oleh karena itu, kesejahteraan anak-anak harus dianggap sebagai kesejahteraan kehidupan manusia. Hasil penyusunan Pasal 28B Undang-Undang Dasar Negara Kesatuan Republik Indonesia ini harus dilakukan pembaruan yang caranya ialah membuat strategi pemerintah yang mengarah pada penjaminan generasi muda. Kepastian anak muda tertuang di Pasal 66 UndangUndang Nomor 39 Tahun 1999 perihal Hak Asasi Manusia.

Mula-mula, tiap anak memiliki hak untuk tak terkena perlakuan kasar, siksaan, dan disiplin. Selanjutnya, deraan hilang nyawa atau deraan seusia hiduptak bisa dipaksakan pada remaja pelaku kejahatan. Ketiga, setiap anak muda memiliki hak untuk tak diingkari kebebasannya secara ilegal. Kemudian, penangkapan, pengurungan atau penahanan seorang anak bisa saja diselesaikan sesuai dengan hukum yang sesuai dan harus dilakukan jika semuanya gagal. Kelima, setiap anak yang ditolak kebebasannya memiliki pilihan untuk ditangani dengan akomodatif dan dengan menghormati kebutuhan kesadaran dirinya sesuaiusianya dan hanya diasingkan dari orang dewasa. Enam, setiap anak yang ditolakkesempatannya memiliki kesempatan untuk memperoleh bimbingan yang sah atau bantuan lain dengan sukses pada setiap tahap pengobatan sah yang bersangkutan. Ketujuh, setiap anak yang ditolak kesempatannya 
Citra Ayu Ramadhanti dan Uu Idjuddin Solihin, Tindak Pidana Pencurian yang dilakukan Anak Usia 14 Tahun dalam Konteks Islam Menghapuskan Tindak PidanaBerdasarkan Pasal 69 Ayat 2 Undang-undang Nomor 11 Tahun 2012 Perihal Sistem Peradilan Pidana Anak (SPPA)

memiliki pilihanuntuk melindungi dirinya sendiri dan mendapatkan keadilan di hadapan pengadilan remaja yang adil dan adil dalam suatu pendahuluan yang tertutup bagi orang-orang pada umumnya. ${ }^{1}$

Dalam Pasal 45 KUHP yang memuat perihal aturan serta usia seorang anak yang bisa dibawa ke persidangan dengan alasan bahwa kesalahan yang dilakukan ialah jika anak itu telah sampai pada usia 16 tahun. ${ }^{2}$ Sementara melihat Undang-Undang Nomor 3 Tahun 1997 perihal Peradilan Anak, Pasal 4 yang mengatur sedapat mungkin anak yang bisa dipidana maupun pemberian kuasa pidana bersifat unik. Di poin itu dijelaskan bahwa usia anak bermasalah yang bisa dibawa ke penyisihan ialah sekitar 8 (delapan) tahun namun belum tiba pada usia 18 (delapan belas) lama serta belum menikah. Pengaturan yang cukup lama dalam pemerataan remaja akan sangat penting dalam memutuskan apakah seseorang dapat dihukum, seperti halnya terlepas dari apakah demonstrasi kriminal dapat dianggap bertanggung jawab kepadanya di bidang kriminal.

Berlawanan dengan deraan menurut Islam, anak tak berkenan ditolakuntuk penyamuan yang telah dia lakukan dengan alasan bahwa tak ada tanggung jawab yang sah kepada keturunan dari segala usia sampai ia tiba pada usia dewasa (baligh), otoritas yang ditunjuk. hanya memiliki opsi untuk mengkritik kesalahan langkahnya atau memaksakan beberapa batasan padanya yang hendakmenolong membenahi juga, cegah dia melakukan kesalahan di kemudian hari. ${ }^{3}$

Di Indonesia, kaidah pidana yang mengatur semua perihal perbuatan salah, pelanggaran juga penertiban bagi mereka, terdapat dalam KUHP, khususnya perbuatan perampokan yang diatur dalam KUHP Buku 11 dalam Pasal 362 sampai dengan Pasal 367. Pasal 362 memberikan pengertian perihal perampokan, dalam Pasal 363 mengarahkan tentang klasifikasi perampokan kecil, Pasal 365 mengatur perampokan dengan kekejaman, dan Pasal 367 mengatur perampokan dalam keluarga. Apalagi pelanggaran yang diperbuat oleh anak juga sudah diatur secara mandiri di Undang-Undang Nomor 3 Tahun 1997 perihal Pengadilan Anak. ${ }^{4}$ Apalagi pengaturan penyelenggaraan jaminan hakhak anak, khususnya spesifikasi Undang-Undang Nomor 23 Tahun 2002 perihal Penjaminan Anak, selain itu pengamanan anak pelaku tindak pidana unjuk rasa juga ada di Pasal 66 Undang-Undang Nomor 39 Tahun 1999 perihal Hak AsasiManusia. Jadi aksi kriminal atau pelanggaran yang dilakukan oleh anak-anak, perlu mendapatkan evaluasi dan pemikiran yang benar-benar tidak biasa, sehingga hakim dalam memberikan izin atau disiplin kepada anak-anak yang melakukan pelanggaran tidak meninggalkan perspektif pelatihan, dan sekali lagi tidak menyalahgunakan keamanan. hak istimewa anak-anak.

Kewajiban pidana dapat diartikan sebagai ketidaknyamanan individu dengan hasil demonstrasi atau kekurangan demonstrasi yang dia lakukan secara mandiri, di mana individu mengetahui tujuan dan hasil kegiatannya. Jika perasaan risiko pidana ini terpenuhi, ada tambahan tanggung jawab pidana. Oleh karena itu, orang dengan kelainan jiwa, anak belum cukup usia, orang yang terkekang tak direpotkan dengan tanggung jawab, dengan alasan tidak ada alasan untuk bertanggung jawab atas mereka. ${ }^{5}$

Sebuah ekspresi penyesalan harus di dunia yang sempurna didasarkan pada perhatian pada beberapa hal yang tidak dapat diterima yang dilakukan danmengatakan 'maaf' kepada orang yang bersangkutan. Perhatian dan penegasan kesalahan yang muncul sejak awal, misalnya sebelum korban mengumumkan atau mencatat keberatan, memungkinkan hukum pidana untuk berubah menjadi ultimum remedium, karena tidak ada persyaratan prosedur hukum terhadapkesalahan tersebut. Dalam interaksi pendahuluan pidana, kebenaran materiil yang harus dicari adalah pokok apakah suatu demonstrasi pidana yang konon dilakukan oleh termohon sebagaimana didakwakan oleh penyidik umum.

Masalah kewajiban bagi anak belum dewasa serta persetujuan pidananya menjadi gagasan yang atraktif untuk ditelaah melihat adanya ketidakkonsistenan baik di aturan positif itu sendiri atapun kaidah pidana Islam. Jadi dalam ulasan ini pembuat teringin untuk mengklarifikasi dan menggambarkan masalah ini dengan judul "Perlindungan Hukum Bagi Pelaku Tindak Pidana Pencurian yang dilakukan Anak Usia 14 Tahun Forgiveness dalam Kontek Islam Menghapuskan Tindak Pidana Berdasarkan Pasal 69 Ayat 2 Undang- undang Nomor 11 Tahun 2012 Perihal Sistem Peradilan Pidana Anak (SPPA)"

Berdasarkan landasan di atas, penulis akan mengkaji pokok permasalahan, khususnya Bagaimana hukum asuransi bagi anak usia 14 tahun menurut Pasal 69 ayat 2 Undang-Undang Nomor 11 Tahun 2012 perihal Sistem Peradilan Pidana Anak, selanjutnya Bagaimana adalah pemeriksaan hukum Islam dan hukum pidana perihal orang

${ }^{1}$ Marlina, Peradilan Pidana Anak di Indonesia, Pengembangan Konsep Diversi dan Restorative Justice, (Bandung: PT Refika Aditama, 2009), hlm 10

${ }^{2}$ Soesilo, Kitab Undang-undang Pidana dan Kitab Undang-undang Hukum Acara Pidana, (Gama Press, 2008), hlm 28

3 Abdur Rahman I, Tindak Pidana dalam Syariat Islam, diterjemahkan oleh Wadi Masturi, Syariah The Islamic Law, (Jakarta : Rineka Cipta, 1992), hlm 16

${ }^{4}$ Wagiati Soetodjo, Hukum Pidana Anak, (Bandung : Rafika Aditama, 2008), hlm 31

${ }^{5}$ Ahmad Wardi Muslich, Pengantar dan Asas Hukum Pidana Islam, (Jakarta : Sinar Grafika, 2006) hlm 74 
Citra Ayu Ramadhanti dan Uu Idjuddin Solihin, Tindak Pidana Pencurian yang dilakukan Anak Usia 14 Tahun dalam Konteks Islam Menghapuskan Tindak PidanaBerdasarkan Pasal 69 Ayat 2 Undang-undang Nomor 11 Tahun 2012 Perihal Sistem Peradilan Pidana Anak (SPPA)

yang diampuni merupakan pembenaran pembatalanUndang-Undang Hukum Pidana 14 Tahun Nomor 11 Tahun 2012 perihal Sistem Peradilan Pidana Anak.

\section{METODE}

Teknik pemeriksaan merupakan komponen penting dan langsung dalam penelitian dan kemajuan ilmu pengetahuan, sebagaimana dicatat dalam penulisanilmiah ini, kegiatan yang menyertainya ialah:

1. Metode pendekatan

Cara penanganan masalah dalam tinjauan ini menggunakan teknik yuridis standarisasi, lebih spesifiknya: suatu metodologi yang dimulai dari penyusunan undang-undang dan ditelaah di lapangan untuk memperoleh variabel pendukung dan hambatan. ${ }^{6}$ Metodologi yuridis standarisasi ini adalah metodologi yang bergantung pada standar atau pedoman hukum yang membatasi dan memiliki hasil yang sah dan jelas. Melalui metodologi yuridis regularisasi ini diandalkan untuk memiliki pilihan untuk memikirkanhukum yang tepat.

2. Spesifikasi penelitian

Pokok-pokok pembahasan dalam penyusunan ini mencakup eksplorasi ilmiah yang jelas, yang menggambarkan persoalan, namun juga membedah persoalan berdasarkan KUHP.

3. Tahap penelitian

a. Penelitian Kepustakaan

Pemeriksaan ini diarahkan untuk mendapatkan informasi opsional melalui bahan-bahan esensial yang halal dan bahan-bahan tambahan yang sah, hal ini diharapkan untuk premis hipotetis (yuridis) seperti halnya data yang diidentifikasi dengan titik eksplorasi..

b. Penelitian Lapangan

Eksplorasi ini diarahkan untuk memperoleh informasi penting, sedangkan informasi yang didapat melalui review ini berasal dari screening.

4. Metode Penggalian Data

Metode pengumpulan informasi dalam ujian ini adalah dengan memanfaatkan studi arsip, screening dan persepsi.

5. Metode Analisis Data

Akhirnya, setiap informasi yang diperoleh pencipta diperiksa denganmenggunakan teknik yuridis pengaturan subyektif. Regularisasi dengan alasan bahwa penjelajahan ini bergantung pada hukum dan pedoman yang ada sebagai hukum tertentu, sedangkan subjektif, yaitu informasi yang diperoleh sengaja disusun untuk penyelidikan tambahan dalam penggambaran kalimat, sehingga tidak menggunakan persamaan matematis.

6. Lokasi Pengkajian

Lokasi yang penyusun pilih sebagai sasaran observasi untukmenyusun penulisan ini ialah wilayah Garut.

\section{HASIL DAN PEMBAHASAN}

\section{Delik Pencurian yang diperbuat Anak Umur 14 Tahun dalam Konteks Islam}

Islam, sebagai keyakinan yang memiliki pelajaran yang lengkap, melimpahi pertimbangan yang luar biasa kepada kehidupan, dalam hal apapun, ketika manusia masih dalam tahap tukik. Meski manusia belum dilahirkan, Islam memberikan hak yang harus terlaksana oleh orang tuanya. Keistimewaan anakadalah komitmen untuk orang tuanya, begitu juga sebaliknya, komitmen anakadalah hak yang harus didapatkan oleh ayah ibunya.

Dalam bermacam-macam tulisan syariat Islam (fiqh) gaya lama, tidak ada sebutan khas bagi gagasan keamanan anak. Sejumlah tulisan syariat Islam (fiqh)gaya lama memakai sebutan hadhanah bisa dikatakan sedikit sama dengan arti penting keamanan anak. Bila diikuti dari awal pentingnya kata tersebut, secarasemantik (etimologis), hadhanah adalah sejenis masdar, yang bermakna "menjaga dan mengajar anak". Sebutan itu bersumber dari al-hishn, yang berartial-janb (perut atau patah), mengingat seorang ibu yang menjelma hadhinah (pembela) menyatukan anak-anak dalam perutnya (masuk). Sementara itu, seperti yang ditunjukkan oleh istilah, hadhanah berarti benar-benar memusatkan perhatian pada anak-anak muda, yang rapuh, yang gangguan jiwa atau yang takwaras, atau mereka yang tak bisa bebas; memenuhi kebutuhan sekolah dan kebutuhan mereka yang berbeda, seperti kerapian, makanan, dan berbagai kebutuhan yang diperlukan untuk bantuan pemerintah mereka. ${ }^{7}$

Dalam Ensiklopedia Islam menegaskan jika menurut etimologis, al- hadhanah bermakna "pelengkap dari bawah ketika mereka datang ke pinggul". Dari segi fiqh, hadhanah mengandung arti benar-benar berfokus pada anak- anak kecil atau anak-anak luar biasa yang tidak atau tidak hidup mandiri, khususnya dengan memenuhi kebutuhan mereka,

${ }^{6}$ Soerjono Soekanto dan Sri Mamudji, Penelitian Hukum Normatif suatu Tinjauan Singkat, (Jakarta : Rajawali, 1985), hlm

\footnotetext{
${ }^{7}$ Abdurrahman al-Jaziri, Kitab fiqih ala al-mazahib al-Arba'ah, (Kairo : al-Hadist, Tanpa tahun), hlm 582
} 
Citra Ayu Ramadhanti dan Uu Idjuddin Solihin, Tindak Pidana Pencurian yang dilakukan Anak Usia 14 Tahun dalam Konteks Islam Menghapuskan Tindak PidanaBerdasarkan Pasal 69 Ayat 2 Undang-undang Nomor 11 Tahun 2012 Perihal Sistem Peradilan Pidana Anak (SPPA)

melindungi mereka dari risiko, memberi mereka pelatihan, dan mengembangkan kapasitas ilmiah mereka sehingga mereka dapat menerima kewajiban hidup. ${ }^{8}$ Al-Juranji memberi makna hadhanah dengan tarbiyat al-walad. ${ }^{9}$ Begitu pula Muhammad al-Syarbini al-Khatib, di bukunya al-Iqna, sesudah menegaskan pentingnya hadhanah dalam bahasa, ia mencirikan hadhanah.

Dalam perspektif syara' dan pemahaman tarbiyah, yang maknanya berurusan dengan orang-orang yang tak dapat menangani diri mereka sendiri, untuk membantu diri mereka sendiri dan menjaga dari kondisi yang dapat menyakiti mereka, meskipun mereka sudah tua karena masalah mental, yang membutuhkan seseorang untuk menangani mereka untuk mencuci mereka, mencuci pakaian mereka, memberkati, dan menerapkan menyembunyikan padanya, atau dengan memegang anak kecil di pangkuannya dan membuatnya istirahat, Hadhanah adalah jenis perwalian dan kontrol. ${ }^{10}$ Selanjutnya, sebutan tarbiyah yang digunakan al-Jurjani dan al-Khatib memiliki makna yang terlampau lebar, yang melingkupi merawat, mendukung serta memastikan.

Beberapa peneliti memadankan makna hadhanah dengan kafalah. ${ }^{11}$ Menurut bahasa hadhanah artinya menjaga, menangani, menopang, merawat, dan mengawasi, sedangkan kafalah artinya memastikan dan menerima pertanggungjawaban atas suatu masalah. Bagaimanapun, al-Mawardi ${ }^{12}$ Pisahkan pentingnya kedua istilah tersebut tergantung pada periode usia dan kemajuan anak. Dua sebutan ini (hadhanah juga kafalah) adalah 2 dari 4 periode seorang anak, yang wajib dipandang sebagai saat terbitnya perpisahanbagi ayah dan ibu si anak. 4 tahapan itu adalah:

1. radha (penyusuan) yakni taraf anak sebelum berusia dua tahun.

2. hadhanah (pengasuhan dan pemeliharaan) yakni taraf anak sebelum mumayyiz (wajarnya sebelum berusia tujuh tahun)

3. kafalah (penjaga dan pelindung) yakni anak yang sudah mumayyiz (kisaran 7 sampai dengan 8 tahun), tetapi belum baligh.

4. kifayah (mencukupi keperluan) khususnya untuk anak-anak telah mencapai kedewasaan dan bebas, jadi mereka dapat mengatasi masalah mereka sendiri. Di tahap 4 ini, takada komitmen wali untuk menangani setiap masalah anak.

Menerawang dari gagasan Perlindungan Anak yang menyiratkan pemuasan hak-hak istimewa anak-anak juga berdasarkan penegasan al- Mawardi di atas, hadhanah (dari sudut pandang terbatas, khususnya mengurusdan mengasuh anak) ialah satu dari sekian jenis asuransi anak. Dengan demikian sesuai dengan penegasan Wahbah al-Zuhaili”'13 yakni hak-hak istimewa anak-anak terdiri atas 5 perihal, khususnya:

1. Nasab (kepribadian).

2. Radha (Menyusui).

3. Hadhanah (Perawat serta Penghidupan).

4. Domain (Perwalian). ${ }^{14}$

5. Nafaqah (Pemberian Nafkah).

Oleh karena itu, seperti yang ditunjukkan oleh al-Mawardi dan al-Zuhaili hadhanah adalah jenis keamanan anak, serta kepribadian memberi, menyusui,perwalian, dan mencari nafkah. Jenis asuransi anak antara lain tergantung pada tahap pembentukan anak. Sesuai dengan yang dijelaskan oleh al-Mawardi sebelumnya, serta sikap al-Zuhaili bahwa domain (perwalian) selesai sesudah tahap hadhanah (pemeliharaan dan pemeliharaan). ${ }^{15}$ Bagaimanapun,dominasi ahli hukum Islam (fiqh) memakai sebutan hadhanah, seperti yangdigambarkan dalam penggambaran sebelumnya, dari perspektif yang lebar, yang melingkupi kepentingan yang setara dengan jaminan anak, untuk lebih spesifik mengumpulkan setiap kebutuhan (secara fisikal maupun persyaratan non-aktual) dari anak-anak yang tak dapat mengelola biayanya. mandiri, mungkin akibat dari anak tersebut masih muda atau karena ketidakmampuan. Dalam

${ }^{8}$ Abdul Aziz Dahlan, Ensiklopedi Islam (Jakarta : Ichtiar Baru van Hoeve, 2005), hlm 229

${ }^{9}$ Ali bin Muhammad al-Jurjāni, al-Ta 'rīfāt (Jakarta : Dar al-Hikmah, Tanpa Tahun), hlm 88

${ }^{10}$ Al-Khathīb, Muhammad al-Syarbini, al-Iqnā`fi Hilli Alfāzh Abi Syujā’ (Bandung: Syirkat al- Ma`ārif li al-Thab`wa alNasyr, Tanpa Tahun), J. 2, hlm 193

${ }^{11}$ Lihat misalnya Ibn Qudāmah, Muwaffiq al-Din Abu Muhammad Abdullah bin Ahmad, al-Mughnī (Beirut: Dār al-Fikr, Tanpa Tahun), J. 9, h. 298-299; Al-Syirazi, Abu Ishaq Ibrahim bin `Ali ibn Yusuf al- Fairuzabadi, al-Muhażżab (Surabaya: alHidayah, Tanpa Tahun), J. 2, hal. 169; al-Nawāwī, Abu Zakariya Muhyiddin Syaraf, al-Majmū` Syarh al-al-Muhażzab (Beirut: Dar al-Fikr, Tanpa Tahun), J. 18, h. 320; al-Syaukāni, Nail al-Authār, Syarh Muntaqāa al-Akhbār (Beirut: Dar al- Fikr, 1994), J. 7, hal $128-132$

12 Al-Māwardi, Abu al-Hasan `Ali bin Muhammad bin Habīb, al-Haw̄̄ al-Kabīr (Beirut: Dar al-Fikr, 1994), J. 15, hlm 100

${ }^{13}$ Wahbah al-Zuhaili, al-Fiqh al-Islamiy, J.10, hlm 245

14 Ibid, hlm 7327.

${ }^{15}$ Ibid, hlm 7328 
Citra Ayu Ramadhanti dan Uu Idjuddin Solihin, Tindak Pidana Pencurian yang dilakukan Anak Usia 14 Tahun dalam Konteks Islam Menghapuskan Tindak PidanaBerdasarkan Pasal 69 Ayat 2 Undang-undang Nomor 11 Tahun 2012 Perihal Sistem Peradilan Pidana Anak (SPPA)

pergantian peristiwa berikutnya, beberapa ahli hukum Islam kontemporer, mengunkapkan sebutan al-walayah dengan makna yangsignifikan terhadap gagasan jaminan anak seperti yang digambarkansebelumnya. Al-Hafnawi, misalnya, menganjurkan bahwa ada dua macam al-domain (perwalian):

1. Perwalian atas pribadi (al-nafs)

2. Perwalian kekayaan (al-mal).

Diwalikannya seorang individu diidentikkan dengan pengejawantahan masalah-masalah yang bersinggungan dengan kebutuhan anak-anak kecil atau orang-orang yang memiliki ketidaksempurnaan (secara jasmani dan rohani), sebagai dukungan (al-hadhanah), pelatihan, pendidikan, juga perkawinan. Sehubungan dengan perwalian kekayaan, yang diberikan kepada individu tidak dapat mengelola sumber daya mereka, entah itu akibat dari mereka belum mencpai kedewasaan dalam usia atau akibat dari mereka tak kompeten. ${ }^{16}$ Adanya pengaturan ini, perawatan anak (hadhanah) penting untuk (al-wilayah).

Begitu pula, Wahbah al-Zuhaili. Padahal al-Zuhaili, seperti halnya diungkapkan di atas, menegaskan jika domain (perwalian) dilakukan sesudah tahap hadhanah (pemeliharaan serta peratawan). ${ }^{17}$ Menyiratkan bahwa hadhanah juga wilayah adalah 2 poin yang unik, namun di lain sisi al-Zuhailimemisahkan wilayah menjadi dua, yakni ruang al-nafs dan ruang al-mal (seperti halnya diungkapkan oleh al-Hafnawi sebelumnya). Wilayah al-nafs menckakup arti penting berurusan dengan segala hal yang berhubungan dengandiri (individu) individu yang kasar (tidak mampu), seperti pertimbangan, pemeliharaan, sekolah, pendidikan, kesejahteraan, pernikahan, dan sebagainya

Menangani segala hal yang berkaitan dengan harta milik orang-orang yang kikuk (yang tidak mampu menyelesaikannya), seperti perbaikan harta benda dan pengurusnya, seperti jual beli, sewa, gadai, dll. ${ }^{18}$

Oleh karena itu, sebutan yang kian absah dipakai untuk pendefinisian perlindungan anak dalam syariat Islam adalah al-region, karena asuransi anak meliputi seluruh perspektif yang terkait dengan anak, entah secara nyata, intelektual, atau mendalam, entah mengenai pribadi sendiri maupun kekayaannya. Berdasarkan penjelasan tersebut, bisa diduga kalau pengertian asuransi anak dalam syariat Islam ialah pemuasan hak-hak istimewa anak danjaminannya dari kondisi-kondisi yang bisa merugikan dirinya, jiwanya, juga kekayaannya, yang meliputi jasmani, rohani, mendalam, juga bagian sosial anak-anak.

\section{Hak-Hak Anak Dalam Islam Hak Hidup}

Islam terlampau menjaga hak hidup tiap orang, meskipun masih berbentuk embrio. Ramai pengulangan dalam kitab suci mencegah dilarangnyamenghilangkan roh makhluk tuhan, entah itu keturunannya atau bukan. Sebagaimana yang diungkapkan dalam Qs. Al-An'am (6):151:

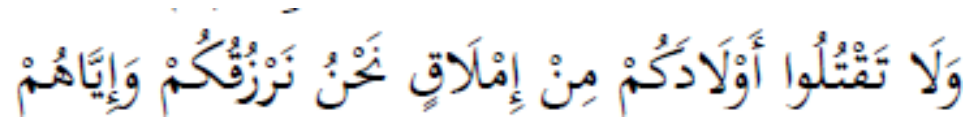

"Juga, jangan bunuh anak-anak Anda yang terinspirasi oleh ketakutan paranoid akan kemiskinan, kami akan memberikan makanan kepada merekasama seperti Anda. Tidak diragukan lagi, menghilangkan nyawa adalah dosa yang luar biasa."

Di bait lainnya, khususnya Q.s Al-Isra (17:31), Allah berfirman:

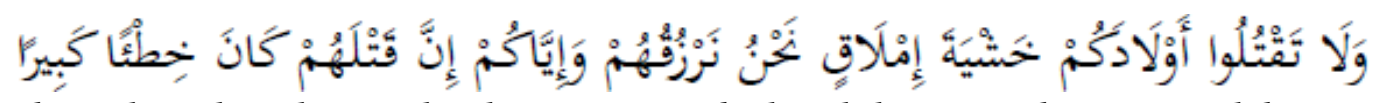

"Selanjutnya, jangan bunuh anak-anakmu karena ketakutan paranoid akan kekurangan harta. Kamilah yang hendak mengasih mereka makan dan terlebih lagi kepada dirimu. Sesungguhnya menghilangkan nyawa adalah dosa yang luar biasa."

Menjadi konsekuensi keberadaan individu yang benar-benar hidup, termasuk anak yang masih dalam perut, Islam menunjukkan semua jenis perawatan, asuransi, dan pemeliharaan embrio, yang dalam penerapannya dibebankan pada bayi. dua wali. Begitu pula ketika anak dikandung, wali wajib menjaga daya tahannya dengan cara mendukung, sungguh-sungguh memusatkan perhatian, dan menanganinya dengan tepat. Allah berfirman dalam Q.S Al-Thalaq (65): 6 :

\footnotetext{
${ }^{16}$ Al-Hafnawi, Abdul Majid Muhammad, Ushūl al-Tasyrī` fì Mamlakah al-`Arabiyyah al-Su ūdiyyah.hlm 227-228

${ }^{17}$ Wahbah al-Zuhaili, al-Fiqh al-Islamiy, J. 10, hlm. 7328

${ }^{18}$ Ibid, hlm. 7327
} 


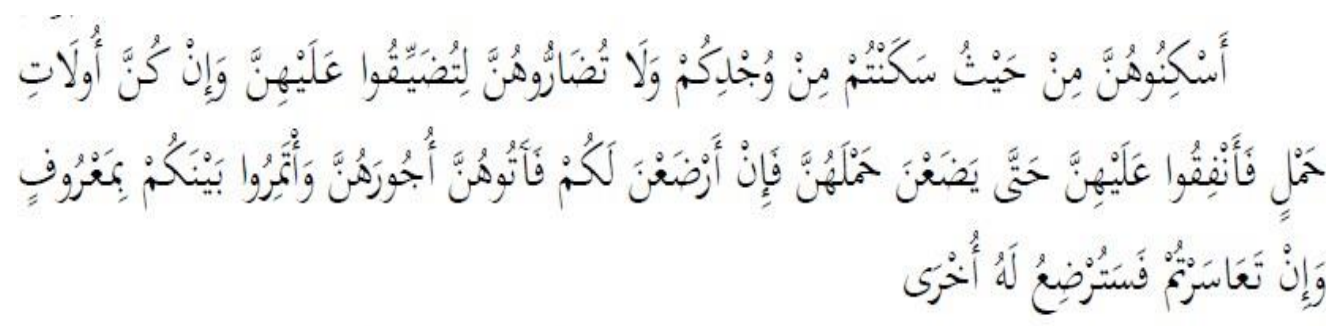

"Temukan mereka (pasangan) tempat tinggal mereka sesuai dengan kemampuannya dan jangan mempersulit mereka untuk membatasi hati mereka. Terlebih lagi, dengan asumsi mereka (pasangan yang berpisah) hamil, beri mereka bisnis mereka sampai mereka mengandung anak., maka,pada saat itu, jika mereka menyusui (anak-anak) Anda sejauh Anda mungkinkhawatir, beri mereka upah mereka; dan konsultasikan di sela Anda (semuahal) sebaikbaiknya; dan jika Anda mengalami masalah, masalah lain wanita mungkin menyusui (anak) untuknya."

Bait di atas menyatakan komitmen para wali untuk benar-benar fokus dan menjaga daya tahan anak-anaknya. Memang, ketika seorang wanita perlu menjalani disiplin untuk perilaku buruknya, sementara di perutnya adatukik, maka pada saat itu, embrio harus dipastikan. Hal ini sebagaimana tercermin dalam serangkaian pengalaman yang dikenal sebagai cerita Ghamidiyah. ${ }^{19}$

Di penggambaran yang berbeda satu perempuan yang membuat kesalahan juga mengharuskan dia ditolak, ketika dia hamil, maka, pada saat itu, hukumannya harus ditangguhkan. Sebuah hadits menyatakan. ${ }^{20}$

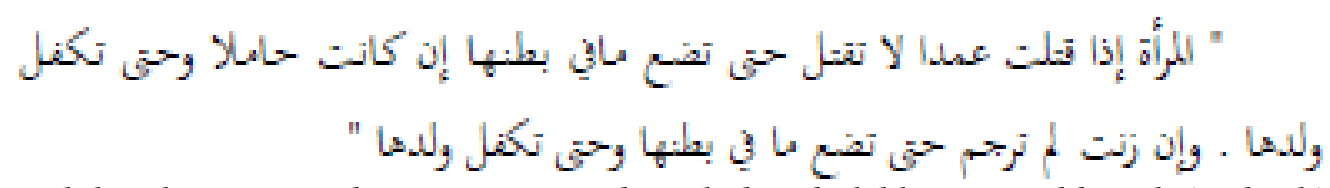

"Seorang wanita, jika dia menghilangkan nyawa dengan sengaja, dia tak diperbolehkan untu dibunuh (qishash) sampai ia mengandung anak, jikadia hamil, dan sampai seseorang berurusan dengan anaknya. Demikian pula, jika dia dia menyerahkan perselingkuhan, dia tidak boleh dirajam sampai dia mengandung anak dan sampai seseorang berurusan dengan anaknya."

Penundaan penghukuman qishash juga rajam seperti yang diungkapkan di penggambaran hadits tersebut menandakan bahwasannya Islam mengkhawatirkan sekali hak-hak istimewa anak, entah sudah dilahirkan atau masih belum dilahirkan (di dalam perut), hingga dijamin anakitu akan hidup tanpa pengabaian oleh Allah.

Dengan ini maka jelas, Allah mengasihkan bantuan dalam bermacam- macam pelaksanaan komitmen untuk wanita (hamil atau menyusui), misalnya, saat dilaksanakannya ibadah puasa di bulan Ramadhan. Sebagaimana diungkapkan di sebuah hadits yang dijelaskan oleh Al-Nasa'i dari Anas Bin Malik :21

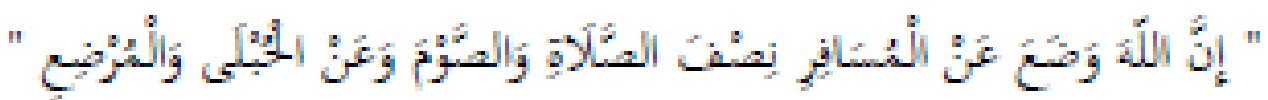

"Yang pasti Allah SWT. Menjatuhkan (melonggarkan) komitmen permohonan para pemudik dan meringankan komitmen puasa (Ramadhan) bagi ibu hamil dan menyusui”.

Memastikan anak-anak benar-benar hidup juga terlihat dari tidak boleh menghilangkan nyawa wanita juga kanak-kanak semasa perang. Di sebuah hadits yang dijelaskan oleh Ibnu Majah diungkapkan :22

19 Abu Dawud Sulaiman bin al-Asy`ats al-Sijistaniy, Sunan Abī Dāwud (Aman: Dar al-A`lam, 2003). Cet. 1, h. 722; Muslim, Shahih Muslim (Indonesia: Dar Ihya' al-Kutub al-`Arabiyah, Tanpa Tahun), Juz 2, hlm. 52. Imam Muslim telah meriwayatkan hadits serupa, yang mengkisahkan cerita yang serupa yang terjadi pada seorang wanita dari Juhainah. Dan Abu Dawud, Sunan Abī Dāwud, hlm 721-722

${ }^{20}$ Ibnu Mājah, Sunan Ibn Mājah, hlm 898-899

${ }^{21}$ Al-Nasā' $\overline{1}$, Sunan al-Nasā' '⿳亠丷厂, Juz 4, hal. 491, no. 2273. Hadits ini juga diriwayatkan oleh al-Turmużi, Sunan al-Turmuż̇..., Juz 2, hlm 109

${ }^{22}$ Ibn Majah Sunan Ibn Majah, Juz 2, hlm 947 


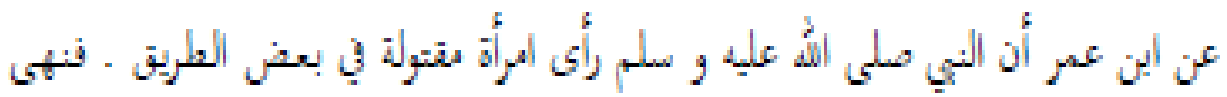

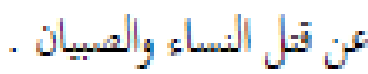

"Dijelaskan dari Ibn Umar, bahwa Nabi melihat seorang wanita yang terbunuh (karena pertempuran) di beberapa jalan. Jadi dia melarang pembunuhan wanita dan anak-anak."

\section{Hak Memperoleh Pengasuhan dan Perawatan}

Mengasuh dan benar-benar fokus pada anak-anak adalah wajib, karena wajib bagi wali untuk memberikan penghidupan yang layak kepada anak- anak mereka. Ini harus dilakukan untuk keuntungan dan daya tahan anak yang sebenarnya. Beberapa peneliti mengatakan bahwa Allah SWT. Akan menganggap wali bertanggung jawab atas anakanak mereka pada Hari Penghakiman, sebelum seorang anak dianggap bertanggung jawab atas orangtua mereka. Oleh karena itu, seperti halnya wali memiliki wewenang atas paraanaknya, seorang anak juga memiliki wewenang atas orang tuanya. Seperti halnya ditunjukkan oleh Al-Qur'an bahwasannya seorang anak wajib berperilaku sopan terhadap ayah ibunya, sebagaimana telah diungkapkan diantaranya di Q.S. Al-Ankabut (29): 8:

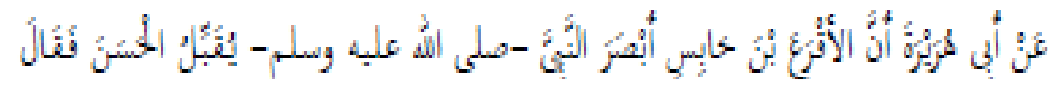

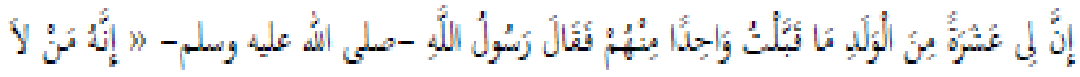

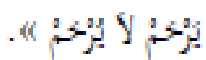

"Selain itu, Kami telah mewajibkan individu untuk berbuat baik kepadaorang-orang mereka."

di Q.S. Al-Tahrim (6):6, Allah berfirman:

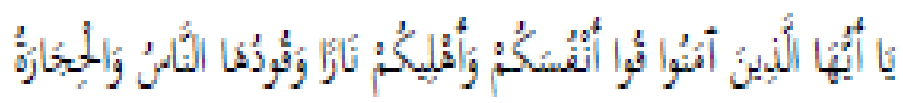

"Hai orang-orang yang menerima, peliharalah dirimu dan keluargamu dari api neraka yang bahan bakarnya adalah individu dan batu."

Bagian sebelumnya menegaskan bahwasannya wali mempunyai kewajiban untuk melindungi serta memelihara anak-anak mereka dan keluarga mereka secara layak. Pada akhirnya, seorang anak memiliki pilihanuntuk benar-benar fokus dan benar-benar diperhatikan oleh ayah ibunya dengan tepat.

Rasulullah SAW. Berikan ilustrasi perihal cara mengambil sikap untuk menghadapi anak, seperti yang dijelaskan dari Abu Hurairah r.a. ${ }^{23}$

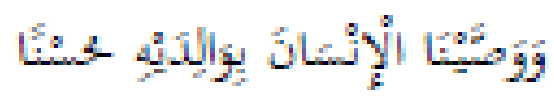

Dari Abu Hurairah r.a. Wadah Aqra itu Setelah menatap Nabi. Mengecup Hasan, kemudian, pada saat itu, berkata: "Tanpa diragukanlagi saya memiliki sepuluh anak dan tidak satupun dari anak saya, saya kecup." Rasulullah saw. Selanjutnya, pada saat itu, berkata: "Tanpa ragu, siapa pun yang tak memuja, tak akan dihargai."

Dalam penggambaran Muslim lainnya, Nabi saw. Bersabda: ${ }^{24}$

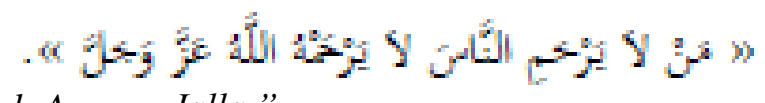

“Orang yang tak menyayangi orang lain, tak akan disayangi Allah Azzawa Jalla.”

\section{Hak Diperlakukan Secara Adil}

Seorang pemuda memiliki hak istimewa untuk mencari penyikapan yangwajar dari ayah ibunya, entah secara

${ }^{23}$ Muslim, Shahih Muslim, Juz 2, h. 325. Lihat juga Sunan al-Turmuż̄, Juz 3, h. 215, no. 1984, 1985, 1986; Sunan Abū Dāwud, Juz 4, h. 255, no. 5218; Ahmad bin Hanbal, Abu `Abdillah, Musnad al-Imām al-Hāfizh Abī `Abdillah Ahmad bin Hanbal, (Riyadh: Bait al-Afkar al-Dauliyyah, 2002), h. 514, no. 7121; h. 525, no. 7287; h. 548, no. 7636; hlm 729

${ }^{24}$ Muslim, Shahih Muslim, Juz 2, h. 325; Lihat juga Ahmad bin Hanbal, al-Musnad (Kairo: Dar al- Hadits, 1995). Cet.1, Juz 14, hlm 407 
Citra Ayu Ramadhanti dan Uu Idjuddin Solihin, Tindak Pidana Pencurian yang dilakukan Anak Usia 14 Tahun dalam Konteks Islam Menghapuskan Tindak PidanaBerdasarkan Pasal 69 Ayat 2 Undang-undang Nomor 11 Tahun 2012 Perihal Sistem Peradilan Pidana Anak (SPPA)

materi maupun non-materi, seperti yangdiungkapkan dalam hadits, termasuk: ${ }^{25}$

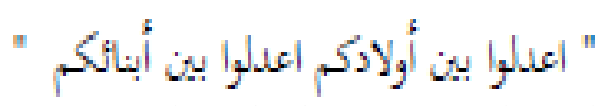

"Bersikaplah masuk akal untuk Anda di antara anak-anakAnda, jadilah wajar untuk Anda di antara anak-anak Anda."

Dalam penggambaran lain, wadah Nu'man Basyir menggambarkan bahwaayahnya memaksa dirinya untuk pergi bersama Rasulullah. Terlebih lagi, katakan: ${ }^{26}$

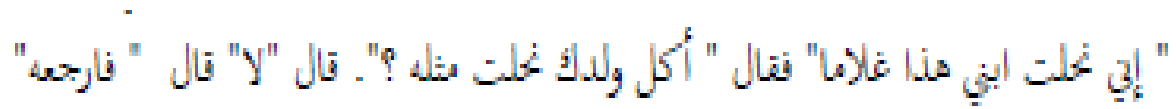

Ayahnya berkata: "Pasti saya memberikan tawanan untuk anak ini." Rasulullah saw. Menanyakan: "Apakah Anda memberikan setiap anak Anda seperti yang Anda berikan untuk anak Anda?" Ayahnya menjawab: "Tidak." Rasulullah saw. Kemudian, pada saat itu, berkata: "(kemudian, pada saat itu)dapatkan kembali hadiahmu."

Hadits di atas menunjukkan komitmen wali untuk bersikap wajar terhadap anak-anaknya: jika salah satu dari anak-anak mereka diberi sesuatu, anak yang lain harus mendapatkan hal yang sama persis. Mentalitas wali yang wajar terhadap anak-anak tidak hanya secara materi, tetapi juga dalam hal-hal non-materi, misalnya memberi kepedulian, cinta kasih, pengajaran, dll.

\section{Pasal 69 ayat 2 Undang-undang Nomor 11 Tahun 2012 Tetang Sistem Peradilan Pidana Anak dengan Hadhanah}

Sebagaimana ditunjukkan oleh Undang-Undang Nomor 11 Tahun 2012 perihal Sistem Peradilan Pidana Anak, Pasal 69 ayat (2) menyatakan bahwa "pemuda yang belum berusia 14 (empat belas) tahun harus diketahui perbuatannya. Sementara itu, Pasal 70 menyatakan bahwa "lunaknya demonstrasi, keadaan anak itu sendiri, atau keadaan di mana kegiatan itu terjadi kemudian dapat dijadikan alasan bagi penguasa yang ditunjuk untuk berpikir untuk tidak memaksakan suatu hukuman atau memaksa suatu kegiatan mengingat perspektif yang sah dan berbelas kasih.

Dalam pengaturan yang tertulis di Undang-Undang Nomor 11 Tahun 2012 perihal Sistem Peradilan Pidana Anak, Pasal 32 ayat 2 menjelaskan bahwa:

(1) Menahan anak tidak bisa diperbuat apabila anak tersebut mendapatkan jaminan yang diberikan oleh ayah ibunya/wali dan tambahan organisasi bahwasannya anak tersebut tak akan lolos, tak akan meniadakan barang bukti, serta tak akan berbuat hal serupa kembali.

(2) Penahanan Anak bisa diterapkan dengan beberapa syarat, diantaranya:

a) Anak tersebut berusia di atas 14 tahun; dan

b) Dikaitkan dengan perbuatan delik yang diancam kurungan diatas 7(tujuh) tahun.

Di Pasal itu penahanan terhadap anak tersebut tak disebut dengan kasus-kasus khusus sebagaimana tercantum dalam Pasal itu. Seharusnya halitu, menjadi pemikiran serius bagi generasi baru sarjana hukum, karena bermacam variabel yang mendasari bahwasannya anak muda sebenarnyamemiliki perjalanan hidup yang masih panjang.

Undang-undang Sistem Peradilan Pidana Anak juga memuat bermacamsesuatu hal yang diwajibkan oleh anak, Pasal 3 menjelaskan bahwa: "tidak boleh ditangkap, ditahan, atau ditahan, apalagi jika semuanya gagal dan dalamwaktu yang sesingkat-singkatnya." Jadi dalam Pasal itu adalah menjelaskan bahwa penahanan/ pendisiplinan yang belakangan ini justru memperlakukan anak-anak sebagai pelaku aksi kriminal, mirip dengan apa yang dilakukan orang dewasa.

Sistem Peradilan Pidana Remaja berdasarkan pendapat Yahya Harahap adalah kerangka kontrol pelanggaran anak, yang terdiri dari lembaga yang melakukan penanganan pemeriksaan anak, penuntutan anak, kontrol anak serta

${ }^{25}$ Abu Dawud, Sunan Abū Dāwud, Juz 3, hlm. 293, no. 3544. Lih juga Sunan al-Nasā̄̄ , Juz 6, hlm 262; Musnad Ahmad, Juz 4, hlm 275, 278, juga 375

${ }^{26}$ Al-Bukhari, Shahīh al-Bukhārī (Semarang: Karya Toha Putera, Tanpa Tahun), Juz 3, hhlm. 206. Lihat juga Musnad Ahmad, Juz 40, hlm. 25, no. 18863; hlm. 69, no. 18907; Sunan al-Nasā' '̌ Juz 6, hlm. 258, no. 3672; hlm. 260, no. 3680; Sunan alTurmuż̄i Juz 2, hlm. 411, no. 1379; al-Baihaqi, Abu Bakr Ahmad bin al-Husain bin Ali, al-Sunan al-Kubrā (Beirut: Dar al-Fikr, Tanpa Tahun), Juz 6, hlm 178-179 
Citra Ayu Ramadhanti dan Uu Idjuddin Solihin, Tindak Pidana Pencurian yang dilakukan Anak Usia 14 Tahun dalam Konteks Islam Menghapuskan Tindak PidanaBerdasarkan Pasal 69 Ayat 2 Undang-undang Nomor 11 Tahun 2012 Perihal Sistem Peradilan Pidana Anak (SPPA)

restoratif anak. ${ }^{27}$ Kerangka kriminal remaja adalah semua komponen kerangka keadilan kriminal yang terlibat dalam mengurus kasus-kasus pengasuhan anak. Mula-mula, polisi selaku lembaga yang tepat ketika seorang anak baru sekali bersinggungan dengan kerangka keadilan, yang juga memutuskan apakah anak itu hendak dilahirkan atau dipersiapkan ke proses diatasnya. Selanjutnya, pemeriksa juga organisasi pembebasan dengan syarat juga akan memutuskan apakah anak tersebut hendak diserahkan atau ditanganidi pengadilan remaja. Lalu, tahap ketika anak muda akan ditetapkan dalam keputusan, mulai dari disampaikan hingga dikenang karena organisasi yang mengutuk. Landasan terakhir dari pendisiplinan. ${ }^{28}$

Bila dilihat dari sudut pandang sosiologis, pelaksanaan keadilan kriminal remaja dapat melukai sisi psikologis, fisik, dan sosial anak. Pelanggaran anak-anak, dewasa ini baik jumlah maupun kualitasnya, pada umumnya akan berkembang dibandingkan dengan berbagai kesalahan, hampir semua kesalahan yang diperbuat manusia yang sudah mencapai kedewasaaannya diperbuat oleh anak-anak. Unsur penyumbang yang berbeda adalah pemerataan keuangan yang kurang menguntungkan, dampak globalisasi di bidang surat menyurat dan data, peningkatan pendidikan serta lifestyle. Dan juga, masalah ini juga lantaran adanya faktor keluarga misalnya tidak adanya perlindungan, kasih sayang, kehangatan juga manajemen dari wali, sehingga anak-anak dengan mudah terpengaruh oleh hubungan yang buruk secara lokal. ${ }^{29}$

Sistem Peradilan Pidana Anak juga diperlukan untuk memanfaatkan pendekatan keadilan yang membantu, menyelesaikan kasus pidana dengan memasukkan pembuat kesalahan, pihak yang dirugikan, kelompok pelaku/korban, juga pertemuan terkait lainnya guna saling mengidentifikasi pengaturan yang wajar dengan menggarisbawahi pembenahan ke keadaannya yang awal, dan bukan pembalasan. Petunjuk pelaksanaan asuransi daerah jikajumlah residivis berkurang, sementara pelakunya berada di bawah pengawasan daerah, daerah memiliki rasa aman dan yakin perihal pekerjaan kerangka keadilan remaja, termasuk sekolah, keluarga, dan yayasan daerah untuk mencegah kesalahan; ikatan dan kombinasi sosial yang diperluas. ${ }^{30}$

Pedoman keadilan terapeutik, yang pada dasarnya merupakan upayauntuk mengalihkan dari interaksi keadilan kriminal ke penyelesaian dengan pertimbangan, tidak dapat diterapkan pada berbagai jenis atau tingkat kesalahan. Meskipun demikian, dalam demonstrasi kriminal tertentu, penggunaan standar ini dapat dianggap jauh lebih layak daripada ukuran keadilan pidana biasa.

Pemerataan pemulihan menurut UU Sistem Peradilan Pidana Anak yangtermuat dalam Pasal 1 angka 6, ialah penanganan kasus dengan mengikutsertakan pembuat kesalahan, pihak yang dirugikan, kelompok pelaku/korban, dan perkumpulan-perkumpulan lainnya yang terkait, guna saling mencari pengaturan yang wajar dengan menonjolkan penyembuhan kembali ke keadaannya yang awal, dan bukan pembalasan. Soal pengasuhan anak-anak yang bergumul dengan hukum, jelas kasus-kasus elektif ditangani tergantung pada satu aturan baku. Misalnya, posisi polisi untuk mempraktikkan kehati-hatian dapat dipraktikkan dalam kasus-kasus apa, parapenegak hukum, khususnya pemeriksa, harus secara efektif mengenali perilaku menyimpang remaja dan pelanggaran yang tidak tercemar. berjuang dengan hukum, sehingga praktik negatif dalam kerangka keadilan kriminal remaja dapat bertahan.

Dalam kepastian Pengadilan Negeri Gunung Sitoli Nomor 1/Pid.Sus- Anak/2014/PN Gst, terdapat seorang remaja berusia 14 (empat belas) tahun yang melakukan perbuatan tercela seperti perampokan. Dalam jaminan ini, hakim meminta persyaratan hukum kepolisian untuk membebaskan anaktersebut dari tahanan. Artinya anak tersebut dikurung dulu, sedangkan sudah jelas tertuang di pengaturan UU SPPA ditegaskan bahwasannya anak yang dicari pengalihan adalah anak yang diancam deraan kurungan tidak lebih dari 7 tahun.

Pasal 32 ayat 2, ditegaskan bahwa "anak-anak tidak boleh dikurung jika mereka mendapat jaminan dari wali/penjaga atau pihak yang berpotensi bahwa anak itu tak akan kabur, tak akan meniadakan dan merusak bukti, dan juga tak akan melakukan perbuatan salah serupa." Pasal tersebut berisi bahwa anak tersebut tidak boleh disimpan jika diperoleh dari orang tua/penjaga dan organisasi bahwasannya anak tersebut tak akan kabur, tak akan meniadakan atau merusak bukti, dan juga tak akan melakukan perbuatansalah serupa. Maknanya, selagi si anak mendapat kepastian dari pertemuan-pertemuan yang sudah disusun sebelumnya, si anak berhak untuk tidak dibatasi. Demikian juga, anak hanya dapat ditahan jika berusia 14 tahun ataupun sudah mapan dan dikaitkan dengan perlakuan pelanggaran dengan dasar penahanan tujuh tahun.

Pengalihan baru saja selesai untuk delik yang diperbuat oleh anak yangdikompromikan dengan hukuman pidana di bawah tujuh tahun. Hal ini sangattidak sesuai dengan situasi yang terjadi, anak tersebut melakukan tindak pidana pembobolan yang deraan ancamannya di bawah tujuh tahun penjara, namun polisi sebagai kuasa hukum utama atas

${ }^{27}$ Yahya Harahap, Pembahsan Permasalahan dan Penerapan KUHP, (Jakarta: Pustaka Kartini, 1993), hlm 5

${ }_{28}$ Mamik Sri Supatmi Purnianti dan Ni Made Martini Tinduk, Analisa Situasi Sistem Peradilan Anak di Indonesia, ( Indonesia: UNICEF, 2003), hlm 5

${ }^{29}$ Nasir Djamil, Anak Bukan Untuk Dihukum, (Jakarta : Sinar Grafika, 2013), hlm 52

${ }^{30}$ Ibid, hlm 48 
Citra Ayu Ramadhanti dan Uu Idjuddin Solihin, Tindak Pidana Pencurian yang dilakukan Anak Usia 14 Tahun dalam Konteks Islam Menghapuskan Tindak PidanaBerdasarkan Pasal 69 Ayat 2 Undang-undang Nomor 11 Tahun 2012 Perihal Sistem Peradilan Pidana Anak (SPPA)

situasi tersebut melakukan penangkapan di bawah pengawasan. mata otoritas yang ditunjuk meminta pengalihan. Penahanan terhadap anak dapat dilakukan apabila perbuatan salah yang dilakukan oleh seorang anak diancam dengan hukuman lebih dari 7 (tujuh) kali atau lebih, hal ini mengandung pengertian bahwa sah untuk keadaan ini polisi tidak boleh menahan anak-anak yang melakukan perbuatantersebut. dari pencurian.

Pasal 6 UU SPPA mengungkapkan bahwa pengalihan diharapkan dapat membebaskan anak-anak dari kesulitan kebebasan. Jika seorang anak ditempatkan ke dalam perawatan, implikasinya anak itu kehilangan haknya sebagai anak-anak negara yang sedang naik daun. Anak-anak tak dapat memperoleh hal yang harusnya mereka dapatkan, dan anak-anak tidak bisa berkembang dan diasuh seperti anak-anak secara keseluruhan.

Anak-anak sebenarnya harus memiliki space guna memenangkan hak- hak istimewa mereka selaku anak-anak sehingga anak-anak dapat dijauhkan dari penghinaan mengerikan yang ditimbulkan oleh disiplin. Anak-anak akan merasa kurang yakin dan tertutup terhadap iklim, karena mereka merasa tidaksama dengan anak-anak yang berbeda. Untuk itu, iklim juga keluarga merupakan 2 poin yang tak bisa terpisahkan dari anak-anak menjadi ruang mendasar mereka untuk bergaul dengan faktor lingkungan mereka.

Aturan dasar untuk melaksanakan gagasan pengalihan adalah aktivitas yang meyakinkan, melimpahi chance untuk orang dapat mengatasi hal salah. Tuntutan hukum dalam melakukan pengalihan menandakan kepentingan patuh terhadap peraturan perundang-undangan dan pedoman yang telah dibentuk. Para ahli hukum melakukan pengalihan secara hati-hati agar anak- anak yang melakukan aksi kriminal tidak merasa takut dan mengalami kekejaman, baik secara nyata ataupun mental.

Pengalihan mengharapkan untuk menjaga anak-anak dari penolakan otonomi. Dalam hal seorang anak ditempatkan dalam kurungan, secara tidak langsung anak tersebut kehilangan haknya sebagai anak-anak desa yang semakin dewasa, anak tersebut tidak dapat memperoleh apa yang seharusnya didapatkan oleh anak tersebut, dan anak tersebut tidak dapat memperolehnya. Mengembangkan dan membina seperti anak-anak secara keseluruhan. Duplikatnya, anak tersebut juga akan mendapat aib negatif dari masyarakat setempat karena mereka menganggap jika anak tersebut ialah anak yang memiliki masalah. Hal ini sangat merajai kenaikan anak-anak dalam keadaanmereka saat ini yang sampai saat ini berharap bahwa anak tersebut bukanlah anak yang baik.

Pedoman yang dibentuk guna mengakomodasi delik-delik dengan pembuat kesalahannya ialah anak di Indonesia pada lazimnya sangat bagus, namun dalam persyaratan hukum dan penerapannya, mereka harus berpegang pada pedoman ini dan pengaturan di mana anak-anak ditemukan. Anak-anak masih perlu memperoleh bagian guna mendapatkan hak-hak istimewa merekaselaku anak-anak agar anak-anak dijauhi dari fitnah mengerikan yang dibawa oleh deraan. Anak-anak akan merasa kurang yakin dan tertutup terhadap iklim karena mereka merasa unik dalam hubungannya dengan anak-anak yang berbeda, untuk itu, iklim serta keluarga ialah dua hal yang tak dapat dipecahkan dari anak-anak seperti tempat mendasar mereka untuk bergaul dengan faktor lingkungan mereka.

\section{SIMPULAN}

1. Demonstrasi perampokan yang dilakukan dengan kemauan keras adalah demonstrasi yang dilarang karena pengambilan barang dagangan atau hak orang lain terhadap demonstrasi itu tergantung pada disiplin dalam jinayah fiqh yang dikenal sebagai jarimah, khususnya orang-orang yang menyalahgunakan prinsip-prinsip yang telah ditetapkan oleh Allah dalam Islam meskipun anak muda sebagai penghibur dalam arahannya, ia sebenarnya perlu mendapatkan beberapa hak, khususnya: hak untuk hidup, pilihan untuk mencari perawatan dan pengobatan dan pilihan untuk ditangani secara wajar.

2. Ada Sistem Peradilan Pidana Anak dengan Hadhanah yang sebenarnya disahkan melalui pendekatan keadilan restroaktif dengan mencoba mengalihkan dari siklus keadilan pidana ke penyelesaian konsultasi sehingga anakanak masih mendapatkan ruang untuk memperoleh hak-hak mereka untuk menghindari pencemaran nama baik yang mengerikan yang ditimbulkan. dengan mengutuk.

\section{DAFTAR PUSTAKA}

\section{Buku}

Al-Bukhari, Shahīh al-Bukhārī (Semarang: Karya Toha Putera, Tanpa Tahun), Juz 3, h. 206. Lihat juga Musnad Ahmad, Juz 40, hal. 25, no. 18863.

69, no.18907; Sunan al-Nasā '̄, Juz 6, h. 258, no. 3672; hal. 260, no. 3680; Sunan al-Turmuż̄̄, Juz 2, hal. 411, no. 1379; al-Baihaqi, Abu Bakr Ahmadbin al- Husain bin Ali, al-Sunan al-Kubrā Beirut: Dar al-Fikr.

Ali bin Muhammad al-Jurjāni, al-Ta 'rīfāt Jakarta : Dar al-Hikmah, Tanpa Tahun. Al-Khathīb, Muhammad al-Syarbini, al-Iqnā’fi Hilli Alfāzh Abi Syujā’, Bandung : Syirkat al-Ma ārif li al-Thab`wa al-Nasyr.

Al-Hafnawi, Abdul Majid Muhammad, Ushūl al-Tasyrì’ fì Mamlakah al’Arabiyyah al-Su'ūdiyyah. Al-Māwardi, Abu al-Hasan `Ali bin Muhammad bin Habīb, al-Hawī al-Kabīr Beirut : Dar al-Fikr, 1994.

Al-Nasā'î, Sunan al-Nasā' '̄, Juz 4, hal. 491, no. 2273. Hadits ini juga diriwayatkan oleh al-Turmużi, Sunan al- 
Citra Ayu Ramadhanti dan Uu Idjuddin Solihin, Tindak Pidana Pencurian yang dilakukan Anak Usia 14 Tahun dalam Konteks Islam Menghapuskan Tindak PidanaBerdasarkan Pasal 69 Ayat 2 Undang-undang Nomor 11 Tahun 2012 Perihal Sistem Peradilan Pidana Anak (SPPA)

Turmuż̄i..., Juz 2.

C, Robert. Trajanowicz an Marry Morash, Juvenile Delniquency. Concept an Control, Prentice Hall, New Jersey, 1992 dalam : Purnianti, Mamik Sri Supatmi dan Ni Made Martini Tinduk, Analisa Situasi Sistem Peradilan Anak di Indonesia, Indonesia : UNICEF, 2003.

Coulson, Noel J. Conflicts and Tensions in Islamic Jurisprudence. Chicago :The University of Chicago Perss.

Dahlan, Abdul Aziz. Ensiklopedi Islam. Jakarta : Hoeve, 2005.

Dawud, Abu. Sunan Abū Dāwud, Juz 3, h. 293, no. 3544. Lih juga Sunan al- Nasā̄̄o, Juz 6, h. 262; Musnad Ahmad, Juz 4, h. 275, 278, dan 375; Abu Fadhl Jamal al-Din, Lisan al-Arab, Jilid XIII, .Berut : Dar al-Kutuh, alIlmiyyah, tanpa tahun.

Djamil, Nasir. Anak Bukan Untuk Dihukum, Jakarta : Sinar Grafika, 2013. Gurvitch, Georges. Sosiologi Hukum, Jakarta : Bharata $1988 \mathrm{M}$.

Harahap, Yahya. Pembahsan Permasalahan dan Penerapan KUHP,Jakarta : Pustaka Kartini, 1993.

I, Abdur Rahman. Tindak Pidana dalam Syariat Islam.

Ibn Majah, Sunan Ibn Majah, Juz 2Ibn Mājah, Sunan Ibn Mājah, Juz 2

Ibn Qayyim al-Jauziyyah Tuhfah al-maurud bi Ahkim al-mauhud, al-Kutubal- Ilmiyyah, 2005.

Khallaf, Abad al-wahhab. Iim Ushul al-fiqh. Beirut : Dar al-Qalam, 1998. Ma'luf, Louis. al-munjid, Beirut : Mathba'ah al-Katulikiyyah, tanpa tahun.

Marlina, Peradilan Pidana Anak di Indonesia Pengembangan Konsep Diversidan Restorative Justice, Bandung : PT Refika Aditama, 2009.

Masturi. Syariah The Islamic Law. Jakarta : Rineka Cipta, 1992.

Muslim, Shahih Muslim, Juz 2, h. 325. Lihat juga Sunan al-Turmuż̄, Juz 3, h. 215, no. 1984, 1985, 1986; Sunan Abū Dāwud, Juz 4, h. 255, no. 5218; Ahmad bin Hanbal, Abu `Abdillah, Musnad al-Imām al-Hāfizh Abī

'Abdillah Ahmad bin Hanbal, (Riyadh: Bait al-Afkar al-Dauliyyah, 2002), h. 514, no. 7121; h. 525, no. 7287; h. 548, no. 7636 ; h. 729 , no. 10684 .

Muslim, Shahih Muslim, Juz 2,; Lihat juga Ahmad bin Hanbal, al-Musnad Cet.1,Juz 14, no. 19089. Kairo : Dar alHadits, 1995.

Muslich, Ahmad Wardi. Pengantar danAsas Hukum Pidana Islam. Jakarta : SinarGrafika, 2006.

Nasution, Harun. Islam ditinjau dari Bebagai Aspeknya, Jakarta : UIPress, 1985 M.

Sulaiman, Abu Dawud bin al-Asy`ats al-Sijistaniy, Sunan Abī Dāwud. Aman :Dar al-A`lam, 2003.

Soesilo, Kitab Undang-undang Pidana dan Kitab Undang-undang Hukum Acara Pidana, Bab III, Hal-hal yang Menghapuskan, Mengurangi atau Memberatkan Pidana Pasal 45, Gama Press, 2008.

Soetodjo, Wagiati. Hukum Pidana Anak, Bandung : Rafika Aditama, 2008. Wahbah al-Zuhaili, al-Fiqh al-Islamiy... J.10.

Wahbah al-Zuhaili, al-Fiqh al-Islamiy..., J. 10. 